\title{
Concentration of zinc in the hair of schoolchildren
}

\author{
NICOLETTA HEINERSDORFF AND T. G. TAYLOR \\ Department of Nutrition, School of Biochemical and Physiological Sciences, University of Southampton
}

SUMMARY The concentration of zinc in the hair of 219 schoolchildren aged between 10 and 11 years was measured and related to height, weight, estimates of consumption of zinc-rich foods, number of children living at home, and rank in family. None of the correlation coefficients between hair zinc and the other variables was significant. Mean concentration of zinc was higher $(\mathrm{P}<0.001)$ in the girls $(146 \mu \mathrm{g} / \mathrm{g} ; 2 \cdot 23 \mu \mathrm{mol} / \mathrm{g})$ than in the boys $(118 \mu \mathrm{g} / \mathrm{g} ; 1.81 \mu \mathrm{mol} / \mathrm{g})$. Eight children $(3 \cdot 7 \%$ of the total $)$ had $<75 \mu \mathrm{g} / \mathrm{g}(<1 \cdot 15 \mu \mathrm{mol} / \mathrm{g})$ zinc in their hair but only one of them was below the 10 th centile for height or weight-a girl with coeliac disease.

A condition of zinc deficiency associated with dwarfism and hypogonadism was first observed in young adult men in Iran (Prasad et al., 1961), and Egypt (Prasad et al., 1963), and it was later reported in 2 young Iranian women (Ronaghy and Halsted, 1975). Zinc deficiency has also been identified in adolescent boys in the Middle East (Ronaghy et al., 1974), and in boys and girls in the USA (Hambidge et al., 1972), but no reports have been published of zinc deficiency in any normal British population.

Zinc deficiency in children before the age of puberty is characterised by retarded growth, poor appetite, and loss of taste acuity (hypogeusia). Hambidge et al. (1972) considered that a hair zinc concentration of $<70 \mu \mathrm{g} / \mathrm{g}(<1.07 \mu \mathrm{mol} / \mathrm{g})$ represented marginal zinc deficiency, and in a group of 132 children aged between 4 and 16 years in Denver, Colorado, 10 had hair zinc concentrations lower than this. Eight of these children had heights at or below the 10th centile on the Iowa growth charts and 5 responded to treatment with zinc.

\section{Methods}

Since the concentration of zinc in hair is often used as an index of zinc-status, we undertook a survey of the zinc content of the hair of 10- to 11-year-old children to see whether or not a deficiency of zinc could be detected. The children came from four different schools in the Southampton area. All the children (403) in this age group were invited to participate

Department of Nutrition, School of Biochemical and Physiological Sciences, University of Southampton T. G. TAYLOR, Rank professor of applied nutrition St George's Hospital, Lincoln

NICOLETTA HEINERSDORFF, house physician in the survey, and 219 agreed. With the exception of 2 Negro children and one Indian child, all were white, The heights and weights of the 219 children were measured, and 157 of them returned the diet sheet and simple questionnaire which they had been asked to complete. The questionnaire contained questions about the date of birth of the child, heights and occupation of the parents, the rank of the child in the family, and whether or not he or she had school meals or was on a special diet (for example, for reasons of health or religion).

Rough estimates of zinc intake were made by classifying foods into 5 categories according to zinc content, class 1 foods (for example fruit, leafy vegetables, butter) containing the smallest amounts of zinc and class 5 (for example, lamb, beef) containing the greatest, and calculating the weight for each category of food eaten.

Samples of hair (10-20 mm in length and weighing about $500 \mathrm{mg}$ ) were taken close to the skin from the same region of the nape of the neck for each child; these were then cut into lengths of 1-2 mm with scissors. After exhaustive washing with acetone, detergent solution (sodium lauryl sulphate, $100 \mathrm{~g} / \mathrm{l}$ ), and distilled water in sequence, followed by a final rinse in acetone, the hair samples were air dried between filter paper. Duplicate samples of approximately $100 \mathrm{mg}$ were digested in $2 \mathrm{ml}$ concentrated nitric acid of a special grade, low in trace elements at $85^{\circ} \mathrm{C}$ for 2 hours in a stoppered tube. After cooling, the digests were made up to $25 \mathrm{ml}$ with glass-distilled water and analysed for zinc by atomic absorption spectrophotometry. Analysis of 13 replicate samples from the hair of one individual gave values with a coefficient of variation of $6 \%$. 


\section{Results}

Correlation coefficients were calculated for each sex between individual hair zinc values and height, weight, number of children living at home, rank in family, and consumption of the different categories of zinc-containing food, and none of these coefficients was statistically significant. The correlation coefficients between number of children living at home and height $(-0.37)$ and weight $(-0.41)$ were, however, significant $(\mathrm{P}<0 \cdot 01)$ as were the correlations between rank in family and height $(-0 \cdot 21)$, and maternal and child's height $(+0 \cdot 23)$.

The mean hair zinc concentration was higher in girls than boys $(\mathrm{P}<0 \cdot 001)$ (Table 1). This large sex difference has not been reported previously in children, probably because no other studies have been carried out with such large numbers of children over such a narrow age range. The distribution of hair zinc values was normal (Table 2). The mean values are similar to those reported by Klevay (1970) for this age group in Panama, but are somewhat lower than the values observed by Hambidge et al. (1972) for American children. Eight children, 6 boys and 2 girls, had $<75 \mu \mathrm{g} / \mathrm{g}$ zinc in their hair but only one of these children was below the 10th centile for height or weight-a girl with coeliac disease.

14 children were found with heights at or below the 10th centile and 19 had weights below this centile but, apart from the girl with coeliac disease, none had hair zinc $<90 \mu \mathrm{g} / \mathrm{g}(<1 \cdot 38 \mu \mathrm{mol} / \mathrm{g})$. There was thus no evidence that short stature and low weight were associated with zinc deficiency, or indeed that the deficiency of zinc suggested by low hair zinc was sufficiently serious to depress growth. All the diet sheets available for the normal children in these subsamples suggested that their diets were adequate

Table 1 Concentration of zinc in the hair of 10- to 11-year-old schoolchildren

\begin{tabular}{lllll}
\hline & & \multicolumn{3}{l}{ Concentration $(\mu \mathrm{g} / \mathrm{g})$} \\
\cline { 3 - 5 } & & Mean & Range & SEM \\
\hline Boys & $(\mathrm{n}=92)$ & 118 & $30-189$ & $3 \cdot 1$ \\
Girls & $(\mathrm{n}=127)$ & $146^{*}$ & $70-235$ & $2 \cdot 8$ \\
\hline
\end{tabular}

Conversion: traditionalunits to $S I-1 \mu \mathrm{g} / \mathrm{g} \approx 0.0153 \mu \mathrm{mol} / \mathrm{g}$

*Significantly greater than the mean for the boys $(P<0.001$, Student's $t$ test). in both quality and quantity, but the records were not sufficiently detailed to permit any accurate calulations of actual zinc intakes to be made.

No assessment was made of the stage of sexual development of the children but it was clear from their heights and weights that whereas most of the girls had entered the adolescent growth spurt, only a few of the boys had done so. Only 6 of the 127 girls had reached the critical weight of $48 \mathrm{~kg}$ which Frisch and Revelle (1971) have related to the menarche. The range of hair zinc of these 6 girls was $90-200 \mu \mathrm{g} / \mathrm{g}(1 \cdot 38-3 \cdot 06 \mu \mathrm{mol} / \mathrm{g})$, a mean of $139 \pm$ $15 \cdot 5 \mu \mathrm{g} / \mathrm{g}$ (SEM) $(2 \cdot 13 \pm 0 \cdot 24 \mu \mathrm{mol} / \mathrm{g})$, indicating that this subgroup did not differ significantly from the whole population.

\section{Discussion}

There was no evidence of a serious deficiency of zinc in these 219 normal children, despite the fact that $3.7 \%$ of them had concentrations of zinc in their hair within the range commonly accepted as indicative of a marginal deficiency.

Requirements for zinc increase at puberty, particularly in boys, presumably associated with the high concentration of zinc present in the testes and accessory male sex glands (Mawson and Fisher, 1953), and a deficiency of this element appears to be more common in males than in females. In this context it is interesting to note that the mean hair zinc concentration was lower in the boys than the girls in this series, suggesting that boys may have smaller body reserves of zinc than girls to support the increased demands of puberty.

A similar sex difference in hair zinc concentration has recently been reported among New Zealand students aged between 18 and 27: in that study the mean hair zinc in the male subjects was $180 \pm 3.9$ (SEM) $\mu \mathrm{g} / \mathrm{g}(2.75 \pm 0.06 \mu \mathrm{mol} / \mathrm{g})$ and in the females $195 \pm 3.1 \mu \mathrm{g} / \mathrm{g} \quad(2.83 \pm 0.05 \mu \mathrm{mol} / \mathrm{g})$ $(\mathrm{P}<0.01)$ (McKenzie, 1979).

A major problem in using hair as a biopsy material for the assessment of trace element status is the danger of contamination by extraneous matter, particularly by cosmetics; whereas superficial 'dirt' is readily removed by efficient washing, lacquers and dyes may be impossible to remove completely by

Table 2 Distribution of zinc concentrations in the hair of 10-to 11-year-old schoolchildren

\begin{tabular}{|c|c|c|c|c|c|c|c|c|c|}
\hline & \multicolumn{9}{|c|}{ Zinc concentration $(\mu \mathrm{g} / \mathrm{g})$} \\
\hline & $25-49$ & $50-74$ & $75-99$ & $100-124$ & $125-149$ & $150-174$ & $175-199$ & $200-224$ & $225-250$ \\
\hline $\begin{array}{l}\text { Boys } \\
\text { Girls }\end{array}$ & $\begin{array}{l}2 \\
0\end{array}$ & $\begin{array}{l}4 \\
2\end{array}$ & $\begin{array}{r}16 \\
9\end{array}$ & $\begin{array}{l}28 \\
15\end{array}$ & $\begin{array}{l}31 \\
45\end{array}$ & $\begin{array}{r}9 \\
35\end{array}$ & $\begin{array}{r}2 \\
16\end{array}$ & $\begin{array}{l}\mathbf{0} \\
\mathbf{3}\end{array}$ & $\begin{array}{l}0 \\
2\end{array}$ \\
\hline
\end{tabular}

See Table 1 for conversion to SI units. 
normal washing. We were certainly aware of these problems and renewed each portion of wash liquid until it remained absolutely clear and colourless, but no comparisons were made between the zinc content of unwashed samples and samples at different stages of the washing process. Although the possibility that the sex difference observed in hair zinc concentrations was due to the greater use of zinc-containing cosmetic preparations by the girls cannot be ruled out entirely, this explanation seems rather unlikely in view of the age of the children, particularly as our mean values were somewhat lower than those reported for American children. Furthermore, McKenzie (1978) showed that treatments such as dyeing, bleaching, and cold waving decrease the zinc concentration of hair. Nevertheless, in retrospect, we wish we had included a question on the use of hair preparations in our questionnaire.

Further studies should be carried out on the zinc status of older children and adolescents. In the Middle East, zinc deficiency is thought to be conditioned by the high phytate content of the staple food of the population, unleavened whole-wheat bread, and the zinc nutrition of the children of Asian immigrants in Britain, many of whom are vegetarians and whose diet includes chappatis made from flour rich in phytate, merits particular study.

We thank the staff, pupils, and parents of Newlands, Wimpson, and Aldermoor Middle Schools, Southampton, and of Abbotswood Primary School, Totton, for their help.

\section{References}

Frisch, R. E., and Revelle, R. (1971). Height and weight at menarche and a hypothesis of menarche. Archives of Disease in Childhood, 46, 695-701.
Hambidge, K. M., Hambidge, C., Jacobs, M., and Baum, J. D. (1972). Low levels of zinc in hair, anorexia, poor growth, and hypogeusia in children. Pediatric Research, 6, 868-874.

Klevay, L. M. (1970). Hair as a biopsy material. I. Assessment of zinc nutriture. American Journal of Clinical Nutrition, 23, 284-289.

McKenzie, J. M. (1978). Alteration of the zinc and copper concentration of hair. American Journal of Clinical Nutrition, 31, 470-476.

McKenzie, J. M. (1979). Content of zinc in serum, urine, hair, and toenails of New Zealand adults. American Journal of Clinical Nutrition, 32, 570-579.

Mawson, C. A., and Fisher, M. I. (1953). Zinc and carbonic anhydrase in human semen. Biochemical Journal, 55, 696-700.

Prasad, A. S., Halsted, J. A., and Nadimi, M. (1961). Syndrome of iron deficiency anemia, hepatosplenomegaly, hypogonadism, dwarfism, and geophagia. American Journal of Medicine, 31, 532-546.

Prasad, A. S., Miale, A., Jr, Farid, Z., Sandstead, H. H., Schulert, A. R., and Darby, W. J. (1963). Biochemical studies on dwarfism, hypogonadism, and anemia. Archives of Internal Medicine, 111, 407-428.

Ronaghy, H. A., and Halsted, J. A. (1975). Zinc deficiency occurring in females. Report of two cases. American Journal of Clinical Nutrition, 28, 831-836.

Ronaghy, H. A., Reinhold, J. G., Mahloudji, M., Ghavami, P., Spivey Fox, M. R., and Halsted, J. A. (1974). Zinc supplementation of malnourished schoolboys in Iran: increased growth and other effects. American Journal of Clinical Nutrition, 27, 112-121.

Correspondence to Professor T. G. Taylor, Department of Nutrition, School of Biochemical and Physiological Sciences, Medical and Biological Sciences Building, Bassett Crescent East, Southampton SO9 3TU.

Received 17 May 1979 